\title{
Effects of Municipal Wastewater Irrigation on Yield and Fertilizer Requirement of Wheat (Triticum aestivum L.) in Bangladesh
}

\author{
M. A. Mojid ${ }^{1}$, G. C. L. Wyseure ${ }^{2}$ and S. K. Biswas ${ }^{3}$ \\ ${ }^{I}$ Department of Irrigation and Water Management, Bangladesh Agricultural University, \\ Mymensingh-2202, Bangladesh; ${ }^{2}$ Division of Soil and Water Management, Department of Earth and \\ Environmental Sciences, KU Leuven, Celestjnenlaan 200E, 3001 Leuven, Belgium; ${ }^{3}$ Irrigation and \\ Water Management Division, Bangladesh Agricultural Research Institute, Gazipur-1701, Bangladesh
}

*Corresponding author and Email: ma_mojid@yahoo.com

Received: 9 January 2016 Accepted: 12 June 2016

\begin{abstract}
Due to increasing scarcity of fresh water, use of unconventional water source (e.g., wastewater) in irrigation has now become important. However, inclusive information on the effects of wastewater on crop production and soil health is necessary for such intervention. This study was designed to evaluate these effects by demonstrating the contribution of municipal wastewater (hereafter called wastewater) on yield and nutrient requirement of wheat (Triticum aestivum L.) cv Shatabdi. Five irrigation treatments $-\mathrm{I}_{1}, \mathrm{I}_{2}, \mathrm{I}_{3}, \mathrm{I}_{4}$ and $\mathrm{I}_{5}$ were tested in a Randomized Complete Block Design (RCBD) with three replications during November-March of 2007-2008, 2008-2009, 2009-2010 at the experimental field of the Bangladesh Agricultural University, Mymensingh. The treatments $\mathrm{I}_{2}-\mathrm{I}_{5}$ consisted of blended wastewater and $\mathrm{I}_{1}$ of fresh water (control). The ratio of wastewater to total irrigation water was $0.25,0.50,0.75$ and 1.0 in $\mathrm{I}_{2}, \mathrm{I}_{3}, \mathrm{I}_{4}$ and $\mathrm{I}_{5}$, respectively. Wheat was cultivated with three irrigations and recommended doses of fertilizer in three consecutive years. Wastewater contained nitrogen $(\mathrm{N})$, phosphorus $(\mathrm{P})$ and potassium $(\mathrm{K}) @ 17.5,3.7$ and $10.3 \mathrm{mg} / \mathrm{L}$, respectively, and irrigation by raw wastewater $\left(\mathrm{I}_{5}\right)$ contributed $19.1,15.1$ and $21.7 \%$ of the recommended $\mathrm{N}, \mathrm{P}$ and $\mathrm{K}$, respectively. Biomass yield increased with increasing fraction of wastewater in irrigation. Grain yield increased for the wastewater fraction of $0.50-0.75$ in irrigation but decreased when irrigation was applied by raw wastewater. Excess fertilizer (under $\mathrm{I}_{5}$ ) boosted up growth of wheat, but did not contribute to the grain yield. Number of grains per spike; and grain, straw and biological yields significantly $(\mathrm{p}=0.05)$ increased due to the contribution of wastewater. Wastewater significantly improved grain and biomass production, with the largest value obtained in $\mathrm{I}_{4}$ (4.61 t/ha grain yield and $11.36 \mathrm{t} /$ ha biomass yield). Raw wastewater in combination with recommended fertilizer doses caused over-fertilization that contributed only in biomass production but not in grain production of wheat and irrigation by wastewater substantially reduced fertilizer requirement of wheat.
\end{abstract}

Keywords: Municipal wastewater, irrigation, fertilizer requirement, wheat

\section{Introduction}

Demand for water, especially in agriculture, is continuously increasing worldwide, and many countries are currently facing water shortages or forecasting its future scarcity. Supplemental water sources and wise use of the available resources are possible solutions to the global problems of water shortage. Municipal 
wastewater is a preferred unconventional supplemental source of irrigation water since its supply is increasing with time due to population growth coupled with augmented awareness of environmental quality and relatively low cost of this water. The cost of wastewater for agricultural use is just the additional cost needed for its application to crop field (Haruvy and Sadan, 1994). Agricultural use of wastewater has the prospect to: (i) reserve local fresh water resources for domestic uses like drinking water, (ii) reduce uncontrolled pollution of the environment, (iii) reduce cost of wastewater treatment, (iv) reduce cost of crop production by supplementing plant nutrients, and (v) provide livelihoods for peri-urban farmers by increasing food production.

However, a wide-ranging knowledge of the effects of wastewater on the growth, yield and yield quality of crops along with its effects on soil health is necessary before recommending irrigation by wastewater. Several investigators (Bielorai et al., 1984; Feigin et al., 1990; Mojid et al., 2012ab; Mojid and Wyseure, 2014) evaluated municipal wastewater for irrigating various crops. Garcia et al. (1999) observed reduced germination and delayed seedling emergence of some crops due to irrigation by wastewater. Irrigation by untreated wastewater is being practiced around several cities in Pakistan because of its high fertility value and role as a conventional method of pollution control (Matsuno et al., 2001). Land application of wastewater is being practiced in India for nonfood crops since time immemorial (Chakrabarti, 1995).

Wheat is a staple food for two-thirds of the world's population (Honsan et al., 1982) and it ranks first both in acreage and production (UNDP and FAO, 1988). Irrigation plays a vital role for its good growth and development (Razzaque et al., 1992). Some agronomic information regarding the feasibility and potential benefits of irrigation by wastewater on some crops and cultivable soils are available (Day et al., 1979; Bielorai et al., 1984;
Chakrabarti and Chakrabarti, 1988 \& 1989). However, these studies were done in climates and under irrigation by wastewater that were of different nature than that in Bangladesh. This experiment was therefore, conducted to investigate: (i) the effects of irrigation by municipal wastewater on growth and yield attributing characters, and water productivity of wheat and (ii) fertilizer contribution of wastewater to wheat cultivation in Bangladesh.

\section{Materials and Methods}

\subsection{Soil, climate and crop-water requirement} An experiment was done with wheat in three consecutive years (November-March of 2007-2008, 2008-2009, 2009-2010) at the experimental field of the Bangladesh Agricultural University at Mymensingh. The site is located in the Agro-Ecological Zone (AEZ) 9 that is situated at $24.75^{\circ} \mathrm{N}$ latitude and $90.50^{\circ} \mathrm{E}$ longitude. Silt loam underlain by sandy loam soil in the field belongs to the Old Brahmaputra floodplain (BARC, 2005). The major characteristics of the top soil were: organic matter $=0.48 \%, \mathrm{pH}=6.8$, field capacity $=$ $38.19 \%(\mathrm{v} / \mathrm{v})$, permanent wilting point $=18.37 \%$ $(\mathrm{v} / \mathrm{v})$, bulk density $=1.33 \mathrm{~g} / \mathrm{cm}^{3}$, and electrical conductivity (EC) of saturation extract (soil : water $=1: 2.5)=0.62 \mathrm{dS} / \mathrm{m}$. The climate is subtropical with an average annual rainfall of 2420 $\mathrm{mm}$ that is concentrated over May to September. The summer is hot and humid, and the winter (November-February) is moderate with only occasional small amount of rainfall in some years. January is the coldest month; the average daily minimum temperature in this month varies from $9.6^{\circ} \mathrm{C}$ to $12.9^{\circ} \mathrm{C}$. During the period of experiments (November-March), the daily minimum temperature varied from 11.70 to $20.72^{\circ} \mathrm{C}$, maximum temperature from 23.47 to $31.95^{\circ} \mathrm{C}$, monthly average relative humidity from 73.57 to $87.55 \%$ and daily pan evaporation from 1.65 to $4.32 \mathrm{~mm}$. A total of $131.3 \mathrm{~mm}$ rainfall occurred in three events (30.6 $\mathrm{mm}$ in January, $5.4 \mathrm{~mm}$ in February and $95.3 \mathrm{~mm}$ in March) during 2007-2008. There was no rainfall during the other two crop years. 
Reference crop evapotranspiration $\left(\mathrm{ET}_{\mathrm{o}}\right)$ was estimated by 'ET ${ }_{0}$ Calculator' based on PenmanMonteith equation (Allen et al., 1998). Crop coefficient $\left(\boldsymbol{K}_{\mathrm{c}}\right)$ values for calculation of cropwater requirements $\left(\mathrm{ET}_{\mathrm{c}}\right)$ were estimated to be $0.3,1.0$ and 0.4 at the initial start, full development and harvest of the crop, respectively. Figure 1 illustrates a 9-day moving average $\mathrm{ET}_{\mathrm{o}}$ during the wheat growing period averaged over 3 years together with $\mathrm{ET}_{\mathrm{c}}$, which were estimated to be $206.8,201.4$ and $191.8 \mathrm{~mm}$ for the wheat seasons of the consecutive years.

\subsection{Experimental plots and treatments}

The experimental land was divided into three equal blocks that contained three replications. Each block was divided into 5 unit plots of size 3 $\mathrm{m} \times 2.5 \mathrm{~m}$. A $1.5 \mathrm{~m}$ buffer zone between the adjacent blocks, and $1.0 \mathrm{~m}$ between the adjacent unit plots were retained to minimize interference effects of the treatments and replications among the plots. The experiment was set up in a Randomized Complete Block Design (RCBD) with three replications. The same plots on the same field layout were used for the same treatments and replications for 3 years' crop cultivation. That is, the same experiment was repeated for 3 years. Five irrigation treatments $\mathrm{I}_{1}$ : fresh water (groundwater extracted with a tubewell) as control, $\mathrm{I}_{2}-\mathrm{I}_{4}$ : blended wastewater (wastewater fraction of $0.25,0.50$ and 0.75 ), and $\mathrm{I}_{5}$ : raw wastewater - were applied to the plots. Urea, triple super phosphate, muriate of potash and gypsum, recommended for wheat cultivation in Bangladesh, were applied in all plots@260, 160,110 and $110 \mathrm{~kg} / \mathrm{ha}$, respectively. Zinc and boron were also applied @ 3 and $1 \mathrm{~kg} / \mathrm{ha}$, respectively to meet up micro nutrient requirements. Two-third of urea and entire doses of the other fertilizers were applied as basal dose; the remainder of urea was top dressed just before first irrigation at 20 days after sowing (DAS). At a good tilth condition of the soil, 2 to $3 \mathrm{~cm}$ deep furrows, with a spacing of $20 \mathrm{~cm}$, were made with hand rakes. Wheat seeds (cv. Shatabdi) were sown manually in the furrows @ $120 \mathrm{~kg} / \mathrm{ha}$ on 12 December in the first year and on 25 November, both in the second and third year crop seasons.

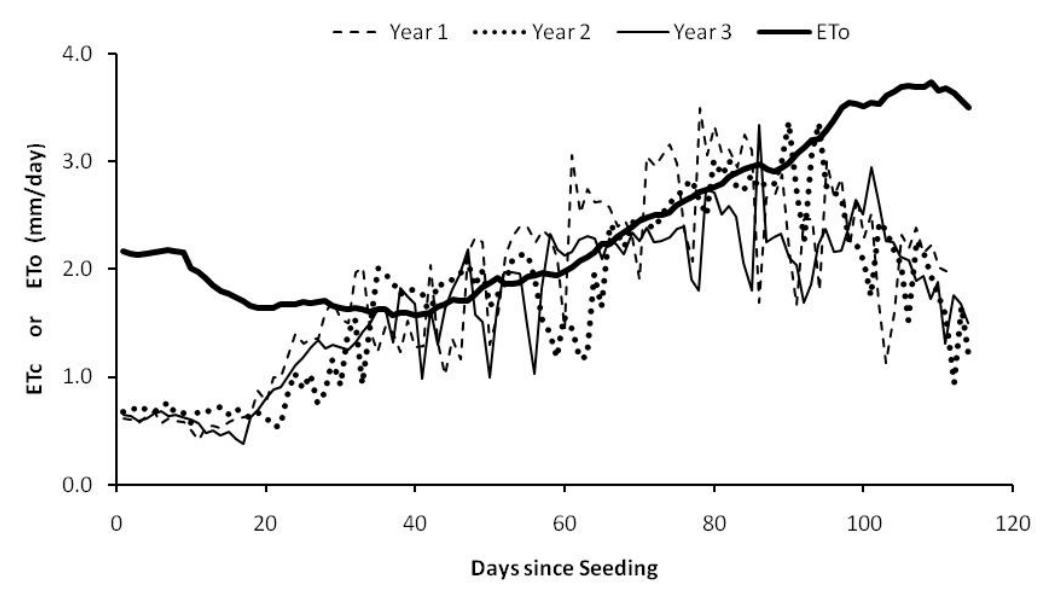

Figure 1. Comparison of crop water requirements, $\mathrm{ET}_{\mathrm{c}}$, for year 1, 2 and 3 with a 9-day moving average reference crop evapotranspiration, $\mathrm{ET}_{0}$, over 3 years' wheat season. During the initial and late growth stages of the crop, $\mathrm{ET}_{\mathrm{c}}$ remained below $\mathrm{ET}_{\mathrm{o}}$ 


\subsection{Collection, preparation and application of wastewater}

Municipal wastewater was collected at $1.5 \mathrm{~km}$ downstream of the main canal from the outlet of the sewerage drainage system of Mymensingh town and carried with a truck. It was dispensed in a sizeable pit near the experimental plots. The pit was lined with a polyethylene sheet to prevent seepage and percolation loss of water. The water in the pit was mixed thoroughly to achieve a homogeneous mixture. Blending of wastewater with fresh water was done in another proximate pit, also lined with a polyethylene sheet, by mixing measured quantity of both waters in compliance with the treatments. Irrigation requirement in the plots was calculated based on root-zone depth and soil-water contents. Irrigation was applied to the plots by check basin method by distributing measured quantity of water manually over the plots with the help of graduated plastic buckets. Samples of raw wastewater, blended wastewater and fresh water were collected and analyzed by a DR/890 Colorimeter (Hach Co., USA) for their chemical properties.

The concentrations of $\mathrm{B}, \mathrm{Fe}, \mathrm{K}, \mathrm{NO}_{3}-\mathrm{N}, \mathrm{PO}_{4}-\mathrm{P}$, $\mathrm{Na}, \mathrm{Pb}, \mathrm{Cu}, \mathrm{Zn}$ and $\mathrm{Cd}$ in the raw wastewater were below their threshold values set by FAO (1992) for safe use in agriculture; only $\mathrm{Mn}$ exceeded the safe limit (Mojid et al., 2010b). The sewage water at Mymensingh was generated mostly from household water usages and partly from a hospital, but none from any industrial source. The electrical conductivity (EC) of fresh water was $0.39 \mathrm{dS} / \mathrm{m}$ and that of raw wastewater ranged between $0.55 \mathrm{dS} / \mathrm{m}$ and $1.05 \mathrm{dS} / \mathrm{m}$. The EC actually dependent on sodium adsorption ratio (SAR) often exceeded the recommended threshold values set by FAO (1992). The wastewater was slightly alkaline with a $\mathrm{pH}$ of 7.33. The chemical oxygen demand (COD) was $181 \pm 25.66 \mathrm{mg} / \mathrm{L}$, which was considered relatively low according to Crites and Tchobanoglous (1998), who reported a COD range of $250-1000 \mathrm{mg} / \mathrm{L}$ for domestic wastewater. The COD is a measurement of the oxygen required to oxidize soluble and particulate organic matter in water. The details of wastewater quality parameters of Mymensingh town are found in Mojid et al. (2010b).

Irrigation was scheduled on the basis of growth stages of wheat - crown root initiation (CRI), booting, flowering and grain filling stages. A total of three irrigations, amounting to 125.0, 135.0 and $132.5 \mathrm{~mm}$ in the first, second and third year, respectively were applied. The first irrigation $(32.5 \mathrm{~mm})$ was at the CRI stage (20 DAS), the second $(42.5,47.5$ and $47.5 \mathrm{~mm}$ in the $1^{\text {st }}, 2^{\text {nd }}$ and $3^{\text {rd }}$ year, respectively) at the booting stage (55 DAS) and the third (50.0, 55.0 and $52.5 \mathrm{~mm}$ in the $1^{\text {st }}, 2^{\text {nd }}$ and $3^{\text {rd }}$ year, respectively) at the grain filling stage (80 DAS). The amount of irrigation was equal to the depth of water required to bring soil water in the root zone to field capacity from existing soil water level. This was calculated from the soil-water content at field capacity, existing soil-water content and root zone depth.

The soil in the field was characteristically homogeneous and so the soil-water contents in the plots were consistent. Consequently, the same quantity of water was applied to each plot in a particular irrigation to achieve an additional control in the treatments. In order to accomplish a controlled water management, the experimental crop was protected from the rainfalls that occurred in the first year by covering the plots with polyethylene sheets. A bamboo-wooden frame was erected on each block containing the replications. The polyethylene sheets were stretched out and kept on the frame only during rainfall; the crop did not encounter any hindrance for getting sunlight beyond the period of rainfall. There was no rainfall during the wheat growing season of the $2^{\text {nd }}$ and $3^{\text {rd }}$ years. It is noted that although there is a considerable variation in the aerial distribution of monsoon rainfall among some regions of the country, such variation is small during winter period. The water management in the experiment is therefore typical for wheat cultivation in Bangladesh. 


\subsection{Intercultural operations, harvesting and data recording}

The experimental plots were kept under regular inspections. Several weeds grew in the plots that were uprooted; the first weeding was at CRI stage after first irrigation and the subsequent weeding was done followed by irrigation. To measure leaf area index (LAI) and above-ground dry matter (ADM) of wheat during the growing period, 10 randomly selected plants from the buffer portion (area surrounding 1 square meter central portion) of each plot were uprooted on $25,45,65,75,95$ and 110 DAS. The leaf area of the plants was measured with a leaf area meter. The LAI for each plot was calculated by the ratio of total leaf area in the sample plants to the average ground area occupied by them. The ground area was calculated from the area of a plot and its plant population. The ADMs of the plots were determined by drying the stems and leaves of the sample plants in oven at $70^{\circ} \mathrm{C}$ for 72 h. At physiological maturity, wheat was harvested from an area of $1 \mathrm{~m} \times 1 \mathrm{~m}$ selected at the middle of each plot; such sampling eliminated the buffer effects of peripheral crops in the plots. After recording plant height and spike length the plant materials were dried in the sun. The spikelets per spike and grains per spike were counted on the dry samples. Thousandgrain weight; grain, straw and biological yields (the latest defined as the sum of grain and straw yields); and harvest index (defined as the ratio of grain to biological yield) were calculated. Water use efficiency for grain and biomass production under different treatments was calculated by estimating the quantity of water used in each plot. Total water used in a plot included the applied irrigation and change in soil water in the root zone between sowing and harvesting of wheat; the contribution of soil water (average for a year) was $43.7,42.8$ and $44.7 \mathrm{~mm}$ in the three consecutive years. The static groundwater level in the field was $10-20 \mathrm{~m}$ below ground surface during the experiment. So, the capillary contribution of groundwater to the crop was ignored; although capillary contribution from the vadose zone (unsaturated below the root zone) might be present. A combined analysis of variance of the growth and yield attributes, grain and biomass yields, and water use efficiency/water productivity of wheat for the three years' experiment was done for the Randomized Complete Block Design (RCBD, 1 factor). The R-package Agricolae (de Mendiburu, 2010) was used for the analysis. The significant level for comparison of different growth and yield attributes was set at $\mathrm{p}=0.05$. Local polynomial regressions were performed by the standard R-loess function in order to identify shape of the relations by the "loess" curve and its confidence limits.

\section{Results and Discussion}

\subsection{Fertility value of wastewater}

Wastewater contained nitrogen $(\mathrm{N})$, phosphorus (P) and potassium $(\mathrm{K}) @ 17.5,3.7$ and 10.3 $\mathrm{mg} / \mathrm{L}$, respectively. The (average) depth of total irrigation and soil moisture contribution from the top $60 \mathrm{~cm}$ profile for a wheat season was $(13.08$ $\pm 0.52)$ and $(4.37 \pm 0.10) \mathrm{cm}$, respectively. Table 1 records the quantities of wastewater applied to different treatments and their contribution to $\mathrm{N}$, $\mathrm{P}$ and $\mathrm{K}$ in the wheat plots. Wastewater, depending on its fraction in the irrigations, contributed $4.8-19.1,3.8-15.1$ and $5.4-21.7 \%$ of the recommended $\mathrm{N}, \mathrm{P}$ and $\mathrm{K}$, respectively to the wastewater-irrigated plots.

\subsection{Growth attributes}

Five growth-attributes of wheat: plant height, spikes per square meter, spike length, spikelets per spike and leaf area index, LAI, measured for the five irrigation treatments were evaluated for their response to irrigation by various proportions of wastewater. Although wastewater always lead to an improvement in the growth attributes, only plant height, spike density and LAI (except at 25 DAS) responded significantly $(p=0.05)$ to the contribution of wastewater when the fraction of wastewater in irrigation was $\geq 0.5$ (Table 2). Plant height increased by 3.7 , 6.7, 6.9 and $9.0 \%$ in treatment $\mathrm{I}_{2}, \mathrm{I}_{3}, \mathrm{I}_{4}$ and $\mathrm{I}_{5}$, respectively over the control treatment, $\mathrm{I}_{1}$. Spike density increased by $0.2,2.2,10.4$ and $13.6 \%$ in $\mathrm{I}_{2}, \mathrm{I}_{3}, \mathrm{I}_{4}$ and $\mathrm{I}_{5}$, respectively over $\mathrm{I}_{1}$. Spike length, 
spikelets per spike and LAI at 25 DAS increased insignificantly compared to $\mathrm{I}_{1}$; the mean values of these attributes for the five treatments were $(10.66 \pm 0.15) \mathrm{cm},(17.22 \pm 0.51)$ and $(0.46 \pm$ $0.02)$, respectively. Although all the growth attributes of wheat improved from treatment $I_{1}$ to $\mathrm{I}_{5}$, the impact of wastewater, however, increased at a decreasing rate as its proportion increased and reached a plateau when irrigation was given with raw wastewater $\left(\mathrm{I}_{5}\right)$.

\subsection{Yield attributes}

The major yield attributes of wheat that responded significantly to irrigation by wastewater are given in Table 3 for the five treatments. Similar to the effects on growth attributes, wastewater always played encouraging roles in the production of yield attributes. Above-ground dry matter, ADM, both at the early stage (25 DAS) and late growth stages (45 and 110 DAS) did not respond significantly to the nutrients $(\mathrm{N}, \mathrm{P}, \mathrm{K})$ supplied by wastewater. The mean ADM for the five treatments at 25, 45 and 110 DAS was $(0.26 \pm$ $0.02),(1.22 \pm 0.09)$ and $(9.95 \pm 0.38) \mathrm{t} / \mathrm{ha}$, respectively. The ADM at 65 DAS continued increasing with increasing quantity of wastewater in irrigation, giving rise to its largest value in $\mathrm{I}_{5}$. In contrast, $\mathrm{I}_{4}$ produced the largest $\mathrm{ADM}$ at $95 \mathrm{DAS}$.

Table 1. Recommended nutrient (Nitrogen, N; Phosphorus, P; Potassium, K) doses for wheat cultivation, nutrient concentration in municipal wastewater (WW), and average quantity of nutrients supplied by wastewater of five irrigation treatments in a wheat growing season

\begin{tabular}{|c|c|c|c|c|c|c|}
\hline Nutrient & $\begin{array}{l}\text { Recommended } \\
\text { nutrient dose } \\
(\mathrm{kg} / \mathrm{ha})\end{array}$ & $\begin{array}{l}\text { Nutrient } \\
\text { conc. in WW } \\
(\mathrm{mg} / \mathrm{L})\end{array}$ & Treatment & $\begin{array}{c}\text { WW applied } \\
(\mathrm{cm})\end{array}$ & 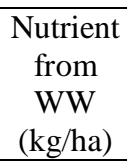 & $\begin{array}{c}\% \text { nutrient } \\
\text { from WW (of } \\
\text { recommended } \\
\text { dose) }\end{array}$ \\
\hline $\mathrm{N}, \mathrm{P}, \mathrm{K}$ & - & 0 & $\mathrm{I}_{1}$ & 0 & 0 & 0 \\
\hline \multirow{4}{*}{$\mathrm{N}$} & \multirow{4}{*}{120} & \multirow{4}{*}{17.5} & $\mathrm{I}_{2}$ & 3.27 & 5.72 & 4.8 \\
\hline & & & $\mathrm{I}_{3}$ & 6.54 & 11.45 & 9.5 \\
\hline & & & $\mathrm{I}_{4}$ & 9.81 & 17.17 & 14.3 \\
\hline & & & $\mathrm{I}_{5}$ & 13.08 & 22.90 & 19.1 \\
\hline \multirow{4}{*}{$\mathrm{P}$} & \multirow{4}{*}{32} & \multirow{4}{*}{3.7} & $\mathrm{I}_{2}$ & 3.27 & 1.21 & 3.8 \\
\hline & & & $\mathrm{I}_{3}$ & 6.54 & 2.42 & 7.6 \\
\hline & & & $\mathrm{I}_{4}$ & 9.81 & 3.63 & 11.3 \\
\hline & & & $\mathrm{I}_{5}$ & 13.08 & 4.84 & 15.1 \\
\hline \multirow{4}{*}{ K } & \multirow{4}{*}{62} & \multirow{4}{*}{10.3} & $\mathrm{I}_{2}$ & 3.27 & 3.37 & 5.4 \\
\hline & & & $\mathrm{I}_{3}$ & 6.54 & 6.74 & 10.9 \\
\hline & & & $\mathrm{I}_{4}$ & 9.81 & 10.11 & 16.3 \\
\hline & & & $\mathrm{I}_{5}$ & 13.08 & 13.48 & 21.7 \\
\hline
\end{tabular}


Table 2. Average plant height, number of spike per square meter and leaf area index (LAI) of wheat under five irrigation treatments over three crop seasons

\begin{tabular}{ccccccc}
\hline & & & \multicolumn{5}{c}{ Leaf area index at } \\
\cline { 4 - 7 } Treatment & $\begin{array}{c}\text { Plant height } \\
(\mathrm{cm})\end{array}$ & $\begin{array}{c}\text { No. of spike } \\
\left(/ \mathrm{m}^{2}\right)\end{array}$ & $\begin{array}{c}45 \\
\text { DAS }\end{array}$ & $\begin{array}{c}65 \\
\text { DAS }\end{array}$ & $\begin{array}{c}75 \\
\text { DAS }\end{array}$ & $\begin{array}{c}95 \\
\text { DAS }\end{array}$ \\
\hline $\mathrm{I}_{1}$ & $90.1 \mathrm{a}$ & $330.6 \mathrm{a}$ & $2.51 \mathrm{a}$ & $2.77 \mathrm{a}$ & $2.48 \mathrm{a}$ & $1.12 \mathrm{a}$ \\
$\mathrm{I}_{2}$ & $93.4 \mathrm{ab}$ & $331.4 \mathrm{a}$ & $2.71 \mathrm{ab}$ & $2.98 \mathrm{a}$ & $2.65 \mathrm{ab}$ & $1.33 \mathrm{ab}$ \\
$\mathrm{I}_{3}$ & $96.1 \mathrm{~b}$ & $337.9 \mathrm{ab}$ & $2.86 \mathrm{ab}$ & $3.26 \mathrm{ab}$ & $2.99 \mathrm{abc}$ & $1.78 \mathrm{bc}$ \\
$\mathrm{I}_{4}$ & $96.3 \mathrm{~b}$ & $365.0 \mathrm{ab}$ & $3.22 \mathrm{~b}$ & $3.57 \mathrm{~b}$ & $3.16 \mathrm{bc}$ & $2.00 \mathrm{c}$ \\
$\mathrm{I}_{5}$ & $98.2 \mathrm{~b}$ & $375.7 \mathrm{~b}$ & $3.24 \mathrm{~b}$ & $3.64 \mathrm{~b}$ & $3.35 \mathrm{c}$ & $2.02 \mathrm{c}$ \\
$\mathrm{HSD}_{0.05}$ & 5.66 & 43.28 & 0.57 & 0.52 & 0.52 & 0.57 \\
\hline
\end{tabular}

Common letter(s) within the same column do not differ significantly at $5 \%$ level of significance analyzed by Tukey's group comparison.

Table 3. Average above-ground dry matter (ADM); grains per spike; and grain, straw and biological yields of wheat under five irrigation treatments over three crop seasons

\begin{tabular}{ccccccc}
\hline & \multicolumn{2}{c}{$\begin{array}{c}\text { Above ground dry matter } \\
\text { Treatment at }\end{array}$} & $\begin{array}{c}\text { No. of } \\
\text { grains/ } \\
\text { spike }\end{array}$ & $\begin{array}{c}\text { Grain } \\
\text { yield } \\
(\mathrm{t} / \mathrm{ha})\end{array}$ & $\begin{array}{c}\text { Straw } \\
\text { yield } \\
(\mathrm{t} / \mathrm{ha})\end{array}$ & $\begin{array}{c}\text { Biological } \\
\text { yield } \\
(\mathrm{t} / \mathrm{ha})\end{array}$ \\
\cline { 2 - 7 } & $\begin{array}{c}65 \\
\text { DAS }\end{array}$ & $\begin{array}{c}95 \\
\text { DAS }\end{array}$ & & & & \\
\hline $\mathrm{I}_{1}$ & $4.148 \mathrm{a}$ & $9.59 \mathrm{a}$ & $36.5 \mathrm{a}$ & $4.04 \mathrm{a}$ & $6.20 \mathrm{a}$ & $10.34 \mathrm{a}$ \\
$\mathrm{I}_{2}$ & $4.291 \mathrm{ab}$ & $10.43 \mathrm{~b}$ & $38.0 \mathrm{abc}$ & $4.27 \mathrm{ab}$ & $6.44 \mathrm{ab}$ & $10.74 \mathrm{ab}$ \\
$\mathrm{I}_{3}$ & $4.520 \mathrm{abc}$ & $10.68 \mathrm{bc}$ & $39.5 \mathrm{c}$ & $4.48 \mathrm{bc}$ & $6.60 \mathrm{ab}$ & $11.11 \mathrm{bc}$ \\
$\mathrm{I}_{4}$ & $4.689 \mathrm{bc}$ & $10.83 \mathrm{c}$ & $38.5 \mathrm{bc}$ & $4.61 \mathrm{c}$ & $6.70 \mathrm{ab}$ & $11.36 \mathrm{c}$ \\
$\mathrm{I}_{5}$ & $4.869 \mathrm{c}$ & $10.74 \mathrm{bc}$ & $37.1 \mathrm{ab}$ & $4.49 \mathrm{bc}$ & $6.77 \mathrm{~b}$ & $11.31 \mathrm{c}$ \\
$\mathrm{HSD}_{0.05}$ & 0.481 & 0.318 & 1.64 & 0.25 & 0.55 & 0.55 \\
\hline
\end{tabular}

Common letter(s) within the same column do not differ significantly at $5 \%$ level of significance analyzed by Tukey's group comparison 
Figure 2 illustrates variation of the ADMs at 65 and 95 DAS in terms of total nitrogen dose that was calculated by adding nitrogen present in the applied irrigation and applied inorganic nitrogen. The quantity of nitrogen was estimated by its average concentration in wastewater, the proportion of wastewater in the applied irrigation and the quantity of irrigation. Treatment $\mathrm{I}_{4}$ produced the largest number of grains per spike (38.5) that were significantly higher than those in $I_{1}$ (36.5). The number of grains per spike increased by $4.1,8.2,5.5$ and $1.6 \%$ in $\mathrm{I}_{2}, \mathrm{I}_{3}, \mathrm{I}_{4}$ and $\mathrm{I}_{5}$, respectively, over the control.

\subsection{Yield and water use efficiency}

Although wastewater contributed in the increase in grain weight of wheat, its impact on 1000grain weight was inconsequential in different irrigation treatments. The mean 1000-grain weight of the treatments was $(44.64 \pm 0.28) \mathrm{g}$. As contrasted in Table 3 and reported in Mojid et al. $(2012 \mathrm{a}), \mathrm{I}_{4}$ produced the largest grain yield (4.61 t/ha), which was significantly different from that in the control (4.04 t/ha). Treatments $\mathrm{I}_{3}$ and $\mathrm{I}_{5}$ produced identical grain yields even though the fertility levels associated with the treatments were different. The grain yield increased by $5.7,10.9,14.1$ and $11.1 \%$ in $\mathrm{I}_{2}, \mathrm{I}_{3}$, $\mathrm{I}_{4}$ and $\mathrm{I}_{5}$, respectively over the control.

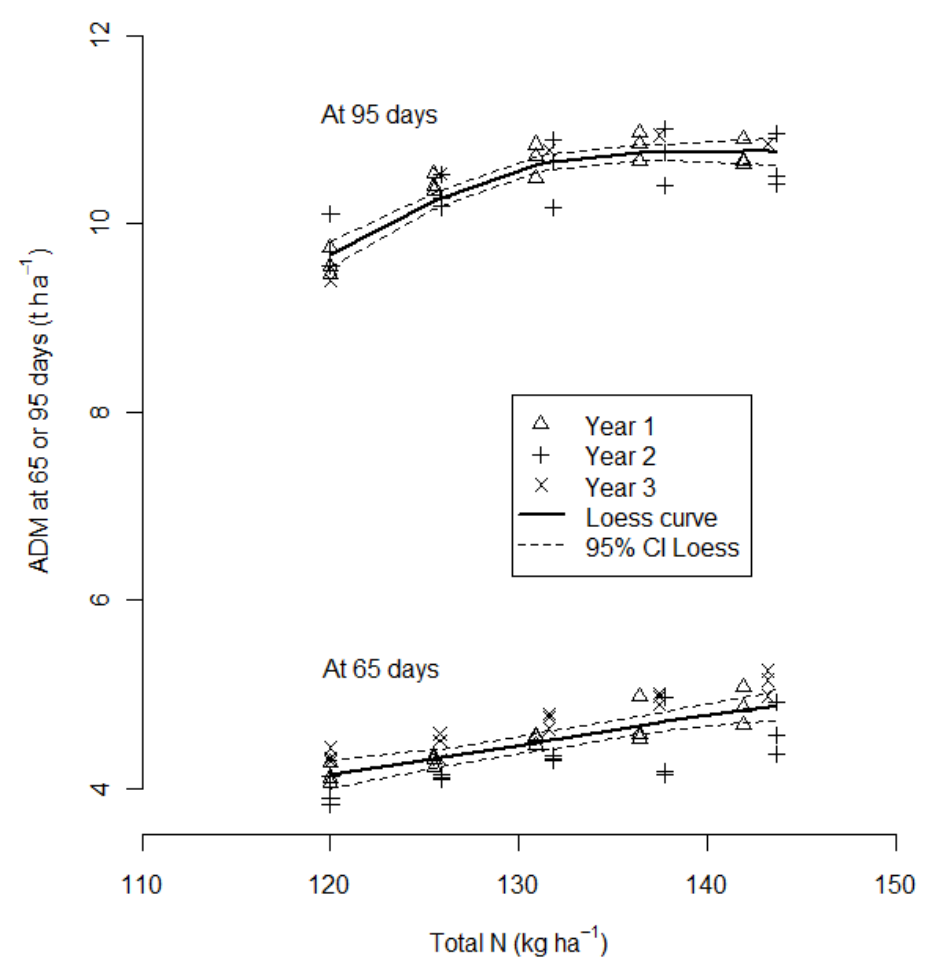

Figure 2. Variation of above-ground dry matter (ADM) of wheat with estimated total nitrogen (N) at 65 and 95 days after sowing (DAS). The ADMs at 25, 45 and 110 DAS did not vary significantly $(\mathrm{p}=0.05)$ and hence were not shown in the plot. The solid line shows the "loess" curve and the dashed lines depict the $95 \%$ confidence limits 


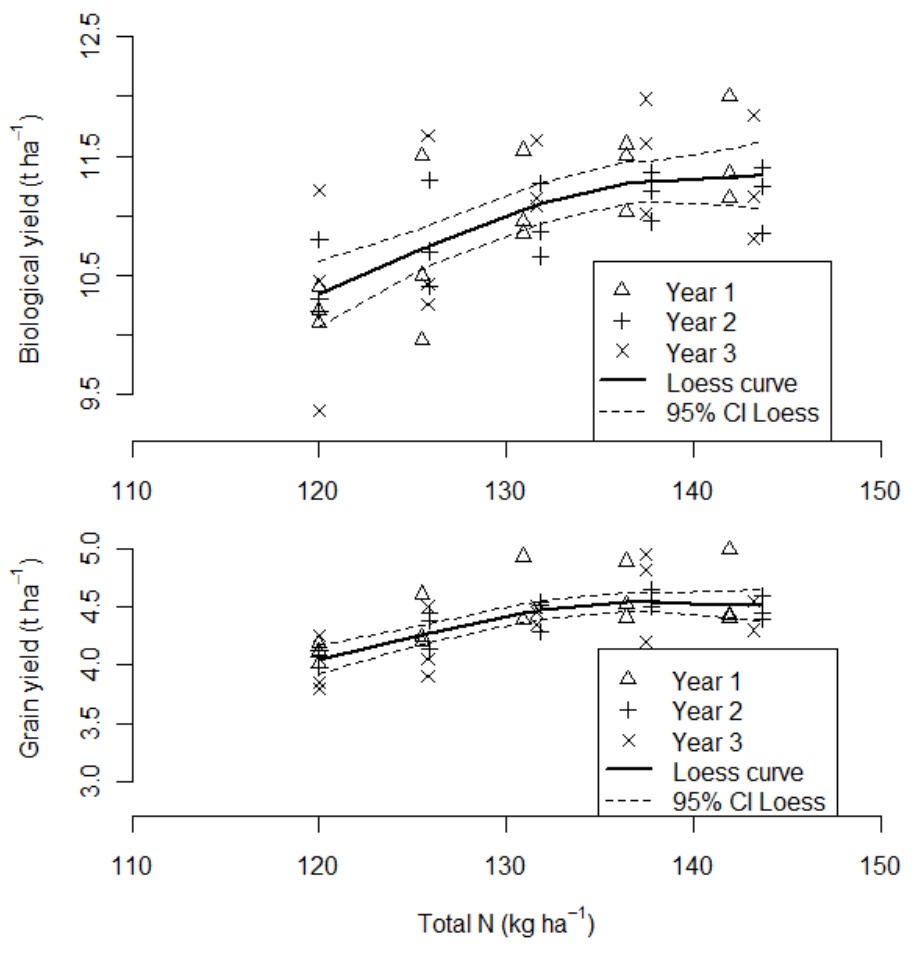

Figure 3. Variation of grain and biological yields of wheat in relation to estimated total nitrogen $(\mathrm{N})$ for individual plots. The solid line shows the "loess" curve and the dashed lines depict the 95\% confidence limits

Straw yield continued increasing (by 3.9, 6.5, 8.1 and $9.2 \%$ ) with increasing proportion of wastewater in the irrigation, giving rise to its largest value in $\mathrm{I}_{5}$. Biological yield under $\mathrm{I}_{4}$ (Table 3), subjugated by the straw yield, was the largest but identical to that under $\mathrm{I}_{5}$. Wastewater contributed increasing the biological yield by 3.9, 7.4, 9.9 and $9.4 \%$ in $\mathrm{I}_{2}, \mathrm{I}_{3}, \mathrm{I}_{4}$ and $\mathrm{I}_{5}$, respectively compared to the control. The harvest index (HI) was statistically identical $(0.40 \pm 0.007)$ in the irrigation treatments. The loess curves of the grain and biological yields as a function of nitrogen dose are depicted in Figure 3 for each plot of the five treatments over 3 years. Wastewater significantly improved the grain and biomass production. The water productivity for grain production was 230.3, $247.4,258.4,260.5$ and $254.2 \mathrm{~kg} / \mathrm{ha} / \mathrm{cm}$ in $\mathrm{I}_{1}, \mathrm{I}_{2}$, $\mathrm{I}_{3}, \mathrm{I}_{4}$ and $\mathrm{I}_{5}$, respectively. The water productivity for biomass production in the corresponding treatments was 588.4, 621.6, 640.3, 641.9 and $639.8 \mathrm{~kg} / \mathrm{ha} / \mathrm{cm}$. Compared to fresh water $\left(\mathrm{I}_{1}\right)$, wastewater boosted up water productivity by 4.0 , $12.2,13.1$ and $10.4 \%$ for grain production and 5.6, 8.8, 9.1 and $8.7 \%$ for biomass production in $\mathrm{I}_{2}, \mathrm{I}_{3}, \mathrm{I}_{4}$ and $\mathrm{I}_{5}$, respectively. Although these treatments resulted in statistically identical water use efficiencies, water was most efficiently utilized by wheat crop under $\mathrm{I}_{4}$. 


\subsection{Contribution of wastewater to plant growth attributes}

Recommended doses of different fertilizers and an identical quantity of irrigation water were applied to all plots; only the quality of irrigation water differed in the five treatments. Wheat plants grew more vigorously in the plots irrigated by wastewater of different dilutions $\left(\mathrm{I}_{2}\right.$ - $\mathrm{I}_{5}$ ) as compared to the plots irrigated by fresh water $\left(\mathrm{I}_{1}\right)$. Such a growth scenario of wheat was similar to that of Chakrabarti (1995) who achieved paramount growth of wheat in the plots irrigated by raw wastewater. The nutrients $(\mathrm{N}, \mathrm{P}$ and $\mathrm{K}$; Table 1) as well as organic matter present in wastewater accumulated in the soil and became available to the plants after mineralization that eventually enhanced the growth of wheat. It is, therefore, revealed that the recommended fertilizer doses (Table 1) were inadequate for the experimental field. The considerable fertilizer content of wastewater can make it a cash incentive to the farmers, who, because of high cost, usually apply much reduced quantity of inorganic fertilizers with a consequent low harvested yield.

The growth attributes of wheat - plant height, spikes per square meter, spike length, spikelets per spike and leaf area index - increased with the increasing quantity of wastewater in the applied irrigation. As the amount of irrigation by wastewater increased, the quantity of $\mathrm{N}, \mathrm{P}$ and $\mathrm{K}$ in the irrigated plots also increased proportionately (Table 1). The increased $\mathrm{N}, \mathrm{P}$ and $\mathrm{K}$ eventually helped augmenting the growth attributes of wheat.

\subsection{Contribution of wastewater to yield attributes and yield}

Like growth attributes, the yield attributes and yield of wheat also improved with the increasing quantity of wastewater in the applied irrigation. Kattimani et al. (1989) also obtained improved growth attributes that contributed to grain yield in wastewater-irrigated plots compared to the freshwater-irrigated plots. Cumulative effects of the yield attributes boosted up both the grain and biological yields of wheat. The nutrient content of wastewater $(\mathrm{N}, \mathrm{P}, \mathrm{K})$ caused superior growth of the wheat plants and, consequently, contributed achieving the maximum grain and biological yields in $\mathrm{I}_{4}$. This result is in conformity with that of Chakrabarti (1995) who obtained the maximum yield of wheat in the plots irrigated by raw wastewater. As was also reported by Mojid et al. (2012a), the raw wastewater combined with the recommended fertilizer doses contributed beneficially to the biomass production but exerted negative influence on grain production with a consequent reduction in grain yield in $\mathrm{I}_{5}$. These results are also in line with the findings of Mojid and Wyseure (2014), who, in a similar experiment with potato over three years, reported that irrigation by a mixture of fresh water and wastewater having 75 and $100 \%$ wastewater in combination with recommended fertilizer dose produced the maximum, but identical, tuber yield. Identical grain yields obtained in $\mathrm{I}_{3}$ and $\mathrm{I}_{5}$ revealed that the negative impact of excess fertilizer in $I_{5}$ was equivalent to the deficit in fertilizer in $\mathrm{I}_{3}$ compared to $\mathrm{I}_{4}$.

Thorough examination of the yield attributes helped elucidate the higher yields obtained in wastewater-irrigated treatments. The larger number of spikelets per spike containing greater number of relatively heavier grains in these treatments compared to the control, contributed to the greater yields. The increased grain yield was an outcome of complex interactions of the yield causative attributes, and it was not possible to interpret them separately in this study. The observed results are fully consistent with the findings of Ghanbari et al. (2007). The improved vegetative growth in terms of plant height and LAI (Table 2) due to the contribution of wastewater elevated the biomass yield, which, in turn, together with yield attributes, boosted up the biological yield. The trend of biological yield in the treatments was in conformity with those of Choukr-Allah et al. (2003) who reported an increasing biological yield of wheat with the increasing amount of wastewater. A substantial quantity of various nutrients in raw wastewater (Table 1) however enhanced vegetative growth 
of wheat and reduced the number of grains per spike and grain weight with a consequent reduction in grain yield in $\mathrm{I}_{5}$. Figure 4 shows the grain yield as a function of biological yield for all plots and years of wheat growth. The loess curve illustrates that a biological yield of more than $11.5 \mathrm{t} / \mathrm{ha}$ leads to a slightly decreasing grain yield. Ensink et al. (2007) pointed out that an unhygienic post harvest handling is often the most important source of contamination of the harvested crops rather than caused by the wastewater irrigation. So, care was taken not to contaminate the grains during the basin irrigation at the later growth stages.

\subsection{Crop-water use}

As provided before, Figure1 illustrates variation of $\mathrm{ET}_{\mathrm{o}}$ and crop-water requirements, $\mathrm{ET}_{\mathrm{c}}(206.8$,
201.4 and $191.8 \mathrm{~mm}$ for 3 consecutive experimental seasons) over the growing season. Because of high monsoon rainfall, soil-water content in the field was close to field capacity during sowing of wheat seeds each year; sowing season was only 1 to 2 months after cessation of monsoon rainfall. Since the total quantity of irrigation for the 3 consecutive years was 135 , 150 and $147.5 \mathrm{~mm}$, it was estimated that a corresponding 71.8, 51.4 and $44.3 \mathrm{~mm}$ water should have been delivered to the crop from other sources, especially from the soil-water reserve. On an average over 3 years and 5 treatments, the difference in soil water in the top $60 \mathrm{~cm}$ soil profile between sowing and harvest of the crop was $44.6 \mathrm{~mm}( \pm 3.7 \mathrm{~mm})$. Considering a plant-available soil-water content of $19 \%$ (volumetric), the total available water reserve in the top $60 \mathrm{~cm}$ soil was estimated to be $114 \mathrm{~mm}$.

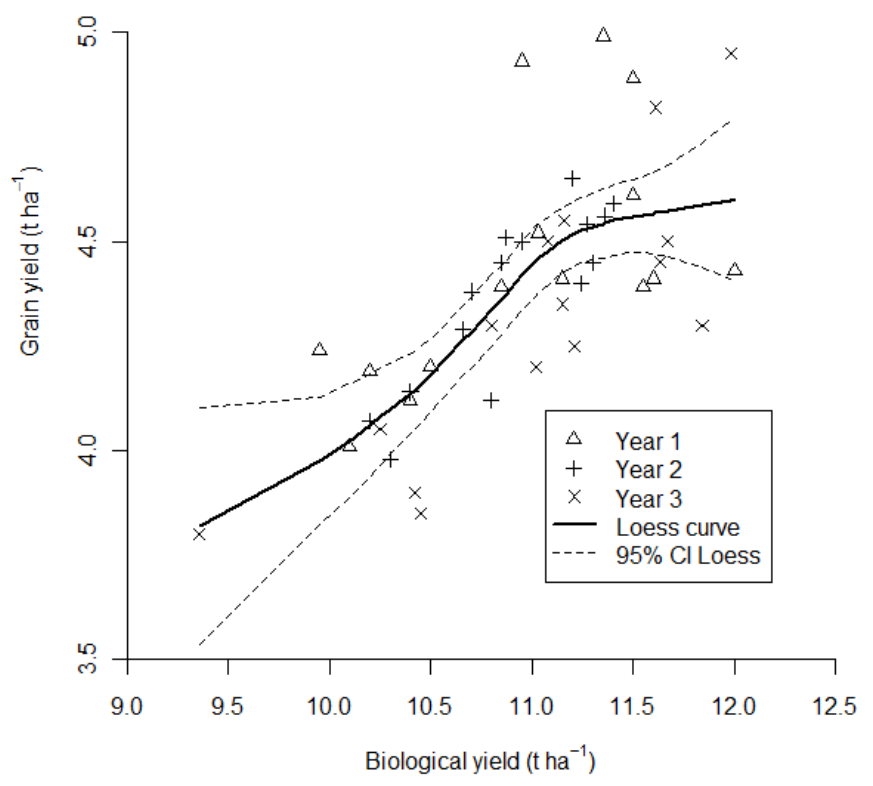

Figure 4. Grain yield of wheat as a function of the biological yield for all plots and years of crop growth. The solid line is the "loess" curve, which illustrates that a biological yield of more than 11.5 t/ha leads to a slightly decreasing grain yield 
The measured soil-water extraction from the 60$\mathrm{cm}$ soil profile was, to some extent, lower than that estimated from a water budget, implying that root water extraction might extend beyond $60 \mathrm{~cm}$ soil profile or, possibly, that seepage from surrounding rice fields and/or capillary rise from below the root zone made a contribution of an extra $20 \mathrm{~mm}$ water to the crop over a season. The total water used (approx. $20 \mathrm{~cm}$ ) in the experiments was lower than the reported average water requirement of wheat $(25 \mathrm{~cm})$ in the study area. The reduced water requirement can, convincingly, be explained by the low evaporative demand (Figure 1.) in the experimental location compared to average evaporative demand of the country $(3.1 \mathrm{~mm} / \mathrm{d})$.

Ali and Talukder (2008) reviewed water productivity (WP) for wheat and showed (in their Figure1), for Mymensingh (the study area), very similar yields of 3.0 to $4.0 \mathrm{t} / \mathrm{ha}$, with a range of irrigation water quantity between $10 \mathrm{~cm}$ and $30 \mathrm{~cm}$. Present experiments produced 4.0 to 4.6 $\mathrm{t} /$ ha grain with $20 \mathrm{~cm}$ water. The improved WP in the wastewater-irrigated plots was in agreement with the findings of Choukr-Allah et al. (2003), who reported an increased WP of wheat under supplemental irrigation using wastewater. The identical WPs in $\mathrm{I}_{2}, \mathrm{I}_{3}, \mathrm{I}_{4}$ and $\mathrm{I}_{5}$ implied that the first small dose of wastewater (25\% of applied irrigation) exerted greater impact on WP than the higher doses. The recommended nutrient doses for wheat (Table 1) was thus inadequate and, at least, an additional $4.8,3.8$ and $5.4 \%$ of the recommended $\mathrm{N}, \mathrm{P}$ and $\mathrm{K}$ (as obtained from wastewater in $\mathrm{I}_{1}$ ) need to be applied for maximum growth of wheat under irrigation by fresh water. Treatment $\mathrm{I}_{4}$, providing the largest WP (also reported by Mojid et al., 2012a), reaffirmed some degree of negative impacts of raw wastewater on wheat production due to over fertilization. So, as a first approach, an equivalent fertilizer in the wastewater needs to be incorporated in the nutrient balance of wheat.

\section{Conclusions}

Irrigation by different proportions of wastewater caused significant increases in plant height, number of spikes per square meter, number of grains per spike; grain and biological yields; and water use efficiency of wheat. Leaf area index (early vegetative stage) and above-ground dry matter (at full vegetative stages) were also increased significantly by wastewater. The nutrients $(\mathrm{N}, \mathrm{P}, \mathrm{K})$ and organic matter contents of wastewater facilitated achieving better growth of wheat plants and augmented the growth and yield attributes. Irrigation by raw wastewater $\left(I_{5}\right)$ produced the maximum plant height, number of spikes per square meter, LAI (except at 25 DAS), ADM (except at 95 DAS) and straw yield. The recommended fertilizer doses were found inadequate for maximizing wheat yield, and additional nutrient from wastewater in the treatments, therefore, contributed maximizing the yield. The raw wastewater, in combination with the recommended fertilizers, although reduced grain yield, contributed to increased biomass yield. Thus, (a) whenever fresh water is not available in peri-urban regions, municipal wastewater can be used for irrigating wheat, and (b) a reduced fertilizer dose, depending on the fraction of wastewater in irrigation, can be applied for better grain yield of wheat, provided that the heavy metal contents of the wastewater, if there is any, do not exceed their threshold values for safe use in agriculture, as in the case for municipal wastewater of Mymensingh.

\section{Acknowledgements}

This study was done under the 'VLIR-Own Initiatives' program with the collaboration of Bangladesh Agricultural University, Mymensingh. The authors acknowledge the funding support of the Belgian Directorate General for Development Cooperation (DGDC) through the 'Vlaamse Interuniversitaire Raad' (VLIR; Flemish Interuniversity Council). 


\section{References}

Ali, M. H. and Talukder, M. S. U. 2008. Increasing water productivity in crop production - a synthesis. Agricultural Water Management, 95: 1201-1213.

Allen, R. G., Pereira, L. S., Raes, D. and Smith, M. 1998. Crop evapotranspiration Guidelines for computing crop-water requirements. FAO Irrigation and Drainage Paper 56, FAO, Rome.

BARC (Bangladesh Agricultural Research Council). 2005. Soil fertility status of different Agro-Ecological Zones. BARC Soils Publication no. 45, 15-32 pp.

Bielorai, H., Vaisman, J. and Feigin, A. 1984. Drip irrigation of cotton with treated municipal effluent: yield response. Journal of Environmental Quality, 13:231-240.

Chakrabarti, C. 1995. Residual effects of longterm land application on domestic wastewater. Environment International, 21:333-339.

Chakrabarti, C. and Chakrabarti, T. 1988. Effects of irrigation with raw and differentially diluted sewage and application of primary settled sewage-sludge on wheat plant growth, yield, enzymatic changes and trace element uptake. Environmental Pollution, 51:219-235.

Chakrabarti, C. and Chakrabarti, T. 1989. Effect of sewage and sludge application on the growth, yield, enzyme activity and micronutrient uptake of cotton crop plants. International Journal of Environmental Studies, 34:169-178.

Choukr-Allah, R., Hamdy, A. and Al-Arawi, S. 2003. Stabilizing rain-fed wheat yield with supplemental irrigation using treated wastewater. Sustainable strategies for irrigation in salt prone Mediterranean region: a system approach. Proceedings of an international workshop, Cairo (Egypt), 8-10 December, 2003, 268-274 pp.

Crites, R. and Tchobanoglous, G. 1998. Small and decentralized wastewater management systems, McGraw-Hill, Singapore.

Day, A. D., Mc Fadyen, J. A., Tucker, T. C. and Cluff, C. B. 1979. Commercial production of wheat grain irrigated with municipal wastewater and pump water. Journal of Environmental Quality, 8: 403-406.

De Mendiburu, F. 2010. Agricolae: Statistical Procedures for Agricultural Research using R. [Online] Universidad Agraria La Molina and Centro International de la Papa. Peru. [Accessed 10 December 2010; Available from http://tarwi.lamolina.edu.pe/ fmendiburu/]

Ensink, J. H. J., Mahmood, T. and Dalsgaard, A. 2007. Wastewater-irrigated vegetables: market handling versus irrigation water quality. Tropical Medicine \& International Health, 12: 2-7.

FAO (Food and Agriculture Organization). 1992. Wastewater treatment and use in agriculture. FAO Irrigation and Drainage Paper 47, 16-17pp.

Feigin, A., Ravina, I. and Shalhevet, J. 1990. Irrigation with treated sewage effluent. Ecological Series, Springer Verlag, New York.

Garcia, O. A., Beltran, G., Uceda, M., Hermoso, M., Gonzalez, P., Ordonez, R. and Giraldez, J. V. 1999. Vegetation water (alpechin) application effects on soils and plants. Acta-Horticulture, 474: 749-752.

Ghanbari, A., Koupai, J. A. and Semiromi, J. T. 2007. Effect of municipal wastewater irrigation on yield and quality of wheat and some soil properties in Sistan Zone. JWSS-Isfahan University of Technology, 10: 59-75. 
Haruvy, N. and Sadan, E. 1994. Cost-benefit analysis of wastewater treatment in the water scarce economy of Israel: a case study. Financial Management and Analysis, 7: 44-51.

Honsan, H., Bolang, N. E. and Anderson, R. G. 1982. Wheat the third world food, West View Press Inc., Colorado.

Kattimani, K. N., Narayana, R. S., Umapathi, P. N., Hanchinal, R. R. 1989. Performance of wheat genotype under limited and adequate irrigation supplies. Current Research, 18: 31-33.

Matsuno, Y., Hoek, V. W., Ensink, J., Aslam, M. R. and Sarfraz, M. 2001. Management of waste water for irrigation in the southern Punjab, Pakistan. $52^{\text {nd }}$ IEC Meeting of the International Commission on Irrigation and Drainage (ICID), International workshop on wastewater reuse management, Seoul (Korea), 19-20 September 2001, 85-94 pp.

Mojid, M. A., Biswas, S. K. and Wyseure, G. C. L. 2012a. Interaction effects of irrigation by municipal wastewater and inorganic fertilizers on wheat cultivation in Bangladesh. Field Crops Research, 134: 200-207.

Mojid, M. A. and Wyseure, G. C. L. 2014. Fertility response of potato to municipal wastewater and inorganic fertilizers. Journal of Plant Nutrition, 37: 1997-2016.
Mojid, M. A., Wyseure, G. C. L. and Biswas, S. K. 2012a. Requirement of nitrogen, phosphorus and potassium fertilizers for wheat cultivation under irrigation by municipal wastewater. Journal of Soil Science and Plant Nutrition, 12: 655-665.

Mojid, M. A. Wyseure, G. C. L., Biswas, S. K. and Hossain, A. B. M. Z. 2010b. Farmers' perceptions and knowledge in using wastewater for irrigation at twelve periurban areas and two sugar mill areas in Bangladesh. Agricultural Water Management, 98: 79-86.

Razzaque, M. A., Suffiun, M. A. and Badruddin, M. 1992. Wheat in national economy in Bangladesh. Adv. Crop Sci. Proc. First Biennial Conference CSSB, 18-20 January, 1992, 13-26pp.

UNDP (United Nations Development Programme) and FAO (Food and Agriculture Organization). 1988. Land resources appraisal of Bangladesh for agricultural development. Report 2. Agroecological regions of Bangladesh. United Nations Development Programme, Food and Agriculture Organization, 212-221 pp. 